\section{Dormancy Release of}

\section{Micropropagated Bulblets of Lilium speciosum after Long Culture in Soil}

\author{
Geert-Jan de Klerk, Isabelle Delvallée, and Annie Paffen \\ Central Research Laboratory for Tissue Culture of Horticultural Crops, \\ P. 0. Box 85, 2160 AB Lisse, The Netherlands
}

Additional index words. bulbs, in vitro culture, lily

\begin{abstract}
Abstact. Micropropagated Lilium speciosum Thunb. bulblets were cold-treated at 2C for various periods before being planted in soil. About $20 \%$ of uoncold-treated bulblets and $100 \%$ of bulblets cold-treated for 6 weeks sprouted within 10 weeks after planting. Intermediate lengths of cold treatment resulted in intermediate percentages of emergence. The remaining $80 \%$ of the noncold-treated bulblets sprouted synchronously from 25 to 33 weeks after planting. In these bulblets, the number of scales increased before sprouting. A sample of bulblets that had received a short cold treatment ( 2 or 3 weeks) also showed biphasic emergence, with the second period between 25 and 33 weeks. When the cold treatment was interrupted by 3 weeks at $17 \mathrm{C}$, the percentage of emergence during the first period was reduced and the timing of the second period advanced.
\end{abstract}

In The Netherlands, 16 million lily bulblets were produced by micropropagation in 1989 (Pierik, 1990). Other bulbous crops are likely to be micropropagated in large numbers in the near future. Since sprouted bulblets are difficult to handle and require acclimatization, micropropagated bulblets should be dormant at harvest. Knowledge of the factors that determine dormancy in micropropagated bulblets is limited. Therefore, we initiated a research program on the development of dormancy during culture in vitro using L. speciosum as a model. We have reported previously that temperature, sucrose concentration, gibberellic acid concentration, and duration of culture have a significant effect on the development of dormancy (Aguettaz et al., 1990; Delvallee et al., 1990). Our article describes dormancy release in micropropagated bulblets. Experiments were conducted to investigate 1) the kinetics of dormancy release during chilling, 2) the effect of an intermittent warm treatment during chilling, and 3) the fate of dormant, nonsprouted bulblets after protracted culture in soil.

Plant material. Field-grown bulbs (circumference 18 to $20 \mathrm{~cm}$ ) of L. speciosum 'Rubrum' no. 10 were harvested in Nov. 1988 and stored at $0.5 \mathrm{C}$ in moistened peat until use. The dormancy status of micropropagated bulblets was not affected by the duration of storage of the starting material (I.

Received for publication 29 Oct. 1990. Accepted for publication 10 Sept. 1991. We thank Y. Niimi (Niigata) and R.J. Bogers (Lisse) for reading the manuscript. This work forms part of an exchange program between the Ministry of Agriculture, Nature Management and Fisheries (The Netherlands), and the Institut National de la Recherche Agronomique (France). The cost of publishing this paper was defrayed in part by the payment of page charges. Under postal regulations, this paper therefore must be hereby marked advertisement solely to indicate this fact.
Delvallée, unpublished observations).

Tissue culture conditions. Scales were surface-sterilized for $30 \mathrm{~min}$ in $1 \%(\mathrm{w} / \mathrm{v}) \mathrm{NaOCl}$. Explants of $7 \times 7 \mathrm{~mm}$ were placed with the abaxial side on $15 \mathrm{ml}$ of medium in $22-\mathrm{mm}$ diameter culture tubes. The medium was composed of MS macro- and microelements (Murashige and Skoog, 1962), and (mg.liter ${ }^{-1}$ ) 30,000 sucrose, 0.4 thiamine, 100 myo- inositol, 7000 agar (Difco-Bacto), and 0.05 1naphthaleneacetic acid. The explants were cultured at 20C (unless indicated otherwise) at a light intensity of $30 \mu \mathrm{mol} \cdot \mathrm{m}-2 \cdot \mathrm{s}^{-1}$ and a 16$\mathrm{h}$ photoperiod from cool-white fluorescent lamps (Philips TL 33).

Cold treatments. Bulblets were harvested from the scales after 15 weeks (unless indicated otherwise) and the leaves and roots removed. Samples of 30 bulblets were treated for $20 \mathrm{~min}$ with $0.2 \%(\mathrm{w} / \mathrm{v})$ Benlate solution, transferred to moistened filter paper in $9-\mathrm{cm}-$ diameter petri dishes, and stored at $2 \mathrm{C}$. In two experiments, the durations of chilling were $0,1,2,3,4,5$, or 6 weeks, in two other experiments $0,2,4$, or 6 weeks, and in a fifth experiment $0,1,3$, or 6 weeks.

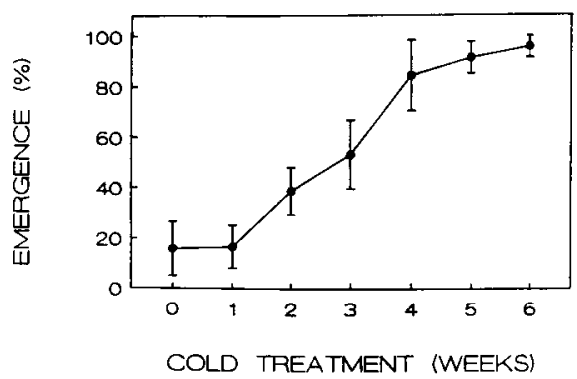

Fig. 1. Emergence of Lilium speciosum bulblets after increasing duration of cold treatment at 2C. Emergence was recorded 10 weeks after transplanting to soil. Each value represents the mean of several determinations with confidence limits at $95 \%$ level, indicated by vertical bars.
Data from the five experiments were combined.

For the chilling treatments of 2 and 3 weeks, an additional experiment was carried out in which chilling was interrupted after 1 week and 2 weeks, respectively, by 3 weeks at $17 \mathrm{C}$.

Culture in soil. After the cold treatments, the samples were planted in steamed potting soil in wooden containers of $23 \times 23 \times 10$ $\mathrm{cm}$ and cultured at $17 \mathrm{C}$ at a light intensity of $20 \mu \mathrm{mol} \cdot \mathrm{m}^{-2} \cdot \mathrm{s}^{-1}$ (cool-white fluorescent lamps) for $16 \mathrm{~h} \cdot \mathrm{day}^{-1}$. The soil was moistened twice a week. Leaf emergence was recorded once per week. All values of emergence refer to samples of 30 bulblets. Each experiment was repeated at least once.

In one experiment, 25 to 30 noncold-treated bulblets were planted in soil and dug up after 12 weeks. The bulblets were dissected and the number of scales determined. Sprouted bulblets were omitted.

Effect of duration of cold treatment. Both conventionally produced lily bulbs (Kamerbeek et al., 1970) and micropropagated bulblets (Higgins and Stimart, 1990; Niimi et al., 1988; Stimart and Ascher, 1981) require chilling to achieve rapid sprouting after planting. The percentage of sprouted bulblets 10 weeks after planting increased with the length of cold treatment (Fig. 1). All bulblets cold-treated for 6 weeks emerged within 10 weeks.

Sprouting of dormant bulblets after protracted culture in soil. About $20 \%$ of the noncold-treated bulblets sprouted during the first 10 weeks after planting. After this, few bulblets sprouted until 24 weeks. Then, within a period of a few weeks (up to 33 weeks), all previously dormant bulblets sprouted (Fig. 2). Samples that had received a cold treatment insufficient to break dormancy in all bulblets ( 2 or 3 weeks at 2C) also showed biphasic emergence. The timing of the second period was not advanced by the cold treatment. In bulblets cold-treated for 4 weeks, however, additional emergence after the first period commenced 12 weeks after planting and extended over a long period.

Increase in the number of scales in dormant bulblets. In vitro lily bulblets continue to form new primordia and scales after the

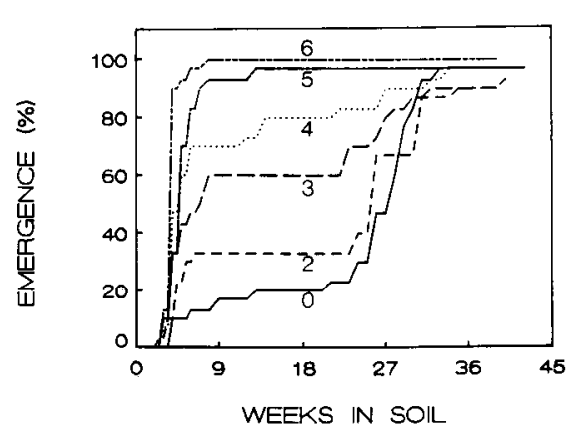

Fig. 2. Emergence of Lilium speciosum bulblets after transplanting into soil. The bulblets were cold-treated at $2 \mathrm{C}$ for $0,2,3,4,5$, or 6 weeks Emergence was recorded weekly. 

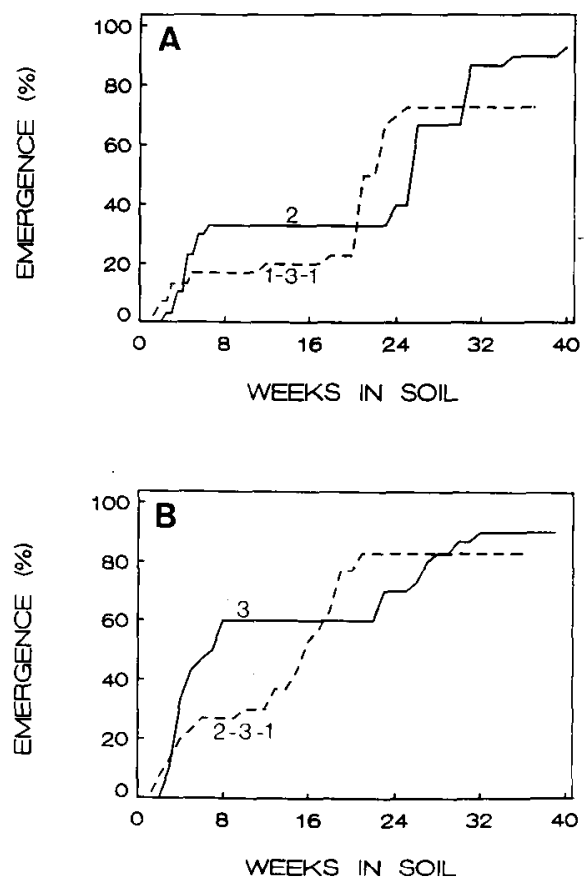

Fig. 3. Emergence of Lilium speciosum bulblets after transplanting into soil. The bulblets were treated for 2 weeks at $2 \mathrm{C}$ with or without an intermittent period of 3 weeks at 17C. (A) $2=$ 2 weeks at $2 \mathrm{C} ; 1-3-1=1$ week at $2 \mathrm{C}-3$ weeks at $17 \mathrm{C}-1$ week at $2 \mathrm{C}$ or for 3 weeks at $2 \mathrm{C}$ with or without an intermittent period of 3 weeks at 17C. (B) $3=3$ weeks at $2 \mathrm{C} ; 2-3-1=2$ weeks at $2 \mathrm{C}-3$ weeks at $17 \mathrm{C}-1$ week at $2 \mathrm{C}$.

Table 1. Number of scales of dormant Lilium speciosum bulblets at the time of transplanting into soil and 12 weeks after transplanting. The bulblets were harvested 11 weeks after the start of tissue culture.

\begin{tabular}{|c|c|c|}
\hline & \multicolumn{2}{|c|}{ No. scales/bulblet ${ }^{2}$} \\
\hline & $20 \mathrm{C}$ & $25 \mathrm{C}$ \\
\hline $\begin{array}{l}\text { Time of } \\
\text { transplanting } \\
12 \text { weeks after } \\
\text { transplanting }\end{array}$ & $\begin{array}{l}4.4 \pm 0.2 \\
5.0 \pm 0.1^{*}\end{array}$ & $\begin{array}{l}4.1 \pm 0.2 \\
5.3 \pm 0.3^{* *}\end{array}$ \\
\hline
\end{tabular}

${ }^{2}$ Values represent the mean of 25 to 30 bulblets \pm SE.

***Increase during culture in soil is significant at $P=0.05$ or 0.01 , respectively according to Student's t test.

induction of dormancy (Delvallée et al., 1990). Consequently, induction of dormancy does not stop growth. We concluded that dormancy in lily corresponds with the inability of the primordium to form a leaf (Delvallée et al., 1990). After planting dormant bulbs in soil, the number of scales increased (Table 1). The increase was similar for bulblets regenerated at 20 and $25 \mathrm{C}$, even though dormancy is deeper in the latter (Aguettaz et al., 1990). The actual number of newly formed scales may be higher than indicated, since the outermost scales may have degraded. Leaves that emerged 25 to 33 weeks after planting did not originate from the primordium present at the time of planting, but from a primordium formed in the soil after planting.

Effect of a cold treatment interrupted by a warm period. When a $2 \mathrm{C}$ treatment of 2 weeks was interrupted by 3 weeks at $17 \mathrm{C}$, the timing of the second period was advanced relative to no interruption (Fig. 3A). Similar results were obtained in an experiment in which a cold treatment of 3 weeks was interrupted by 3 weeks at 17C (Fig. 3B). These data show that the timing of the second period depends only on the number of weeks at high temperature and not on the weeks at $2 \mathrm{C}$.

Apart from a marked effect on the timing of the second period, an intermittent warm period also reduced the effect of the chilling treatment. Similar results have been reported for buds in woody crops (Saure, 1985). We have previously observed that a short period at $20 \mathrm{C}$ induces dormancy in bulblets that were not dormant (Delvallée et al., 1990). Possibly the intermittent period at $17 \mathrm{C}$ induced dormancy and thereby reduced the emergence during the first period.

\section{Literature Cited}

Aguettaz, P., A. Paffen, I. Delvallée, P. van der Linde, and G.J. de Klerk. 1990. The development of dormancy in bulblets of Lilium speciosum generated in vitro. I. The effects of culture conditions. Plant Cell Tissue Organ Cult. 22:167-172.
Delvallte, I., A. Paffen, and G.J. de Klerk. 1990. The development of dormancy in bulblets of Lilium speciosum generated in vitro. II. The effect of temperature. Physiol. Plant. 80:431-436.

Higgins, W.S. and D.P. Stimart. 1990. Influence of in vitro generation temperature and post-in vitro cold storage duration on growth response of Lilium longiflorum bulblets. J. Amer. Soc. Hort. Sci. 115:930-933.

Kamerbeek, G.A., J.C.M. Beijersbergen, and P.K Schenk. 1970. Dormancy in bulbs and corms. Proc. 18th Intl. Hort. Congr., Tel Aviv, vol. 5. p. $233-240$.

Murashige, T. and F. Skoog. 1962. A revised medium for rapid growth and bioassays with tobacco tissue cultures. Physiol. Plant. 15:473497.

Niimi, Y., Y. Endo, and E. Arisaka. 1988. Effects of chilling- and $\mathrm{GA}_{3}$-treatments on breaking of dormancy in Lilium rubellum Baker bulblets cultured in vitro. J. Jpn. Soc. Hort. Sci. 57:250-257.

Pierik, R.L.M. 1990. Vegetatieve vermeerdering in kweekbuizen in Nederland: grotere bedrijven en een stijgend aantal planten. Vakbl. Bloem. 45(23):32-33.

Saure, M.C. 1985. Dormancy release in deciduous fruit trees. Hort. Rev. 7:239-300.

Stimart, D.P. and P.D. Ascher. 1981. Foliar emergence from bulblets of Lilium longiflorum Thunb. as related to in vitro generation temperatures. J. Amer. Soc. Hort. Sci. 106:446450 . 